\title{
ASSESSING THE PERCEPTION OF STAKEHOLDERS REGARDING THE IMPACT OF COASTAL TOURISM ON THE ENVIRONMENT IN THE ROMANIAN BLACK SEA COASTAL AREA
}

\author{
Mari-Isabella Stan \\ Ovidius University of Constanta, Romania \\ Kamer-Ainur Aivaz \\ Ovidius University of Constanta, Romania \\ Dragoş-Florian Vintilă \\ Ovidius University of Constanta, Romania \\ Ionela Ionițiu \\ Ovidius University of Constanta, Romania
}

\begin{abstract}
The coastal and marine area is one of an endlessly increasing number of human activities and provisions, the most significant of which are those associated with tourism. With the start of the MARSPLAN BS-II project in 2019, the planning of public participation actions of stakeholders to identify areas and important features for each maritime activity to develop and implement MSP has started. This study, using an appropriate exploratory approach, namely Grounded Theory, aims to assess stakeholders' perceptions of the environmental impact of tourism in the Romanian Black Sea coastal area to identify potential barriers that may arise from the perspective of implementing the Black Sea MSP. Even if the impact of tourism on the environment cannot be studied in-depth and fully proven, it is obvious, through our results, that tourism should fully enjoy the management and planning efforts.
\end{abstract}

Keywords: coastal tourism, environment, stakeholders, Maritime Spatial Planning (MSP), Grounded Theory

DOI: http://dx.doi.org/10.15549/jeecar.v8i4.695

\section{INTRODUCTION}

Management is considered by many to be one of the most creative arts, as it aims to direct the talents of many actors involved in activities entailing social, economic, technological, political, and human change. In terms of coastal areas, management involves the management of coastal areas to balance the environment, the economy, human health, and human activities, activities that involve the participation of all 
those who have interests in this area or are directly or indirectly affected.

Coastal areas are under pressure due to community enlargement, perpetual diversification of human activities, and climate change. Therefore, it is necessary to protect and develop coastal areas under sustainable development conditions (Rempis et al., 2018). As it can be seen in reality, however, not all of these measures and actions are always included in the maritime spatial plans.

The importance of studying coastal areas is justified by the multitude of existing resources in this area, by the ecosystem facilities, and by the main contribution to socio-economic progress (Petrișor et al., 2020). Modern economic research requires a non-standard approach, measures, and diagnostic tools for economic processes for both government and communities (Megits, 2020), and there are proposals for assessing the impact of sustainability in maritime spatial planning based on ecosystem services (Frederiksen et al., 2021). Therefore, to get a holistic approach, the planning process must take into account a whole range of environmental, social, and economic issues.

The natural and anthropic tourist potential of the Romanian coastal area has left its mark in the development of tourism as a preponderant economic activity. With a high degree of complexity, coastal tourism influences the economic and social development of the area, which is why, in the context of maritime planning, it must efficiently integrate the interest of stakeholders and experts in these processes (Ólafsdóttir, 2020).

The need to develop maritime space management based on development plans was exhibited in the first recital of Directive 2014/89/EU.

Maritime Spatial Planning (MSP) is a procedure and a tool that protects the marine environment and contributes to the long-lasting development of economic activities in the area. It also adopts science-oriented management actions and allows for the long-lasting socio-economic and ecological development of coastal and marine areas (Ehler, 2014). Throughout this process, the engagement of stakeholders has a decisive part in environmental decision-making. It is also a key principle in maritime spatial planning and integrated coastal zone management (Schumacher et al., 2018).

This study aims to assess the perception of stakeholders regarding the impact of tourism in the Romanian Black Sea coastal area on the environment to identify potential barriers that could arise from the perspective of maritime spatial planning in the Black Sea.

\section{ROMANIAN BLACK SEA COASTAL AREA}

The coastal area is extremely important for a European country in post-communist transition, such as Romania, to assess the impact of economic development on the environment generated by these activities (Petrișor, 2014). The resources offered by the Romanian coastal area provide the necessary support for an extremely varied multitude of human activities. It is often argued that the Black Sea is one of the most devalued seas in the world and that its environment has been characterized by the absence of management policies that have brought about declining marine supplies and high-rise levels of degradation and pollution (Avoyan et al., 2017).

The Black Sea coastal area on Romania's territory spreads from Musura Bay to the north (border with Ukraine) and Vama Veche to the south (border with Bulgaria), on the territory of Tulcea and Constanţa counties. It is split into two major areas: the northern area, between Musura Bay and Cap Midia, (165 km long), and the southern area, between Cap Midia and Vama Veche, (approximately $82 \mathrm{~km}$ long). Most human settlements and a belt of tourist resorts, including three port areas and tourist beaches, are situated in the southern part, whereas in the northern part, there is the deltaic coast of the Danube River. The coastal and marine zone is the area of an unceasingly rising number of human affairs and services, the most relevant of which are those associated with coastal and maritime tourism (Papageorgiou, 2016). The Romanian Black Sea coast assembles significant natural and anthropic characteristics at the national and international levels and represents 5.3\% of the total Black Sea coast (Văidianu \& Ristea, 2018). The proportion of coastal tourism is estimated at approx. $60 \%$ of the total tourist registrations at the national level, which is why tourism has become one of the most important and 
representative economic activities in the Romanian coastal area.

The study area overlaps with a territory that is abundant in natural and anthropogenic tourist resources. The southern part of the Black Sea coast has a natural tourist potential that is imposed both by long sandy beaches and seawater and by the spa resources, which gives the Romanian coast a wide range of tourist motivations: rest, sports, spa complex. The anthropic tourist potential is dominated by archeological vestiges and ruins of fortresses, historical monuments, art and architecture, museums, and memorial houses.

In the northern coastal area, the natural tourist potential is given by the Danube Delta, the largest delta in Europe, inscribed in the UNESCO natural heritage since 1991 and classified as a biosphere reserve at the national level, one of the most important tourist areas at the national level through the originality of the complex landscape. The Danube Delta is endowed with various natural and anthropic tourist resources. On its territory, there are several objectives of tourist interest: places of worship, historical monuments, archeological sites, protected areas, natural areas.

In this context, it becomes very obvious that the sustainable development of the Black Sea coastal area of Romania is a complex and sensitive issue, which raises several quite different social, economic, and environmental issues.,Therefore it is necessary to take into account the interactions of economic, environmental and social factors (Filip et al., 2016); it should be perceived as a multiform notion, which consists of four piles: economic, social, environmental and cultural, with different dimensions, plus a territorial dimension, not to be neglected (Petrișor, 2014).

The development of human activities in the coastal and marine areas causes additional tensions on ecosystems and disputes and disagreements between marine users, requiring up-to-date management schemes. The perspective of sustainable development resides on the balance between economic activities and their impact on the coastal environment (Munteanu, 2021). Identifying synergies, transnational coordination and coordinated actions are indispensable to evolve an effective approach of MSP management to resolve tensions and encourage multiple uses and activities (Gómez-Ballesteros et al., 2021).

In partnership with Bulgaria, Romania is currently running the MARSPLAN BS-II project (2019-2021), which aims to develop a common MSP strategy based on the results obtained and which should lead to the development of maritime spatial plans for both countries in 2021. The elaboration and implementation of the maritime spatial planning plan must be done with the consultation and involvement of the stakeholders, the competent public administration authorities, and the target public involved in this process.

Thus, MSP can bring a meaningful contribution to acquiring a good, decent ecological rating in the Black Sea, and its implementation in Romania must be achieved by learning from the experiences and proposals of various stakeholders in this maritime space by conducting an ex-ante evaluation (Văidianu \& Ristea, 2018).

\section{LITERATURE REVIEW}

A review of the literature reveals numerous studies, research, and analyses on maritime spatial planning aimed at promoting the longlasting expansion of marine zones and the equitable usage of marine supplies, especially interactions in which human activities have an influence or impact on the environment.

The concept of sustainability emerged at the height of a crisis between economic development and its social and environmental consequences, aiming to reconcile them (Petrişor et al., 2020). One of its advantages is the capacity to line up collective development regulations with existing certain, distinct situations and conditions (Berezina et al., 2020), sustainable economic development involving environmental protection, ensuring decent living and working conditions, as well as providing sufficient resources (Shpak et al., 2021).

The coastal area hosts a great diversity of economic activities, which is why it must be seen from the perspective of sustainable development based on the three traditional pillars - economic, social, and environmental, to which the cultural pillar was added (Petrişor, 2017). The sustainable 
development perspective requires simultaneous communication between the different levels of governance with the participation of stakeholders.

Coastal areas are some of the main important tourist areas in the world. In this context, coastal and maritime tourism is one of the most significant constituents of the tourism industry with the most prevailing human interest in the coastal area, which is why it is frequently accountable for controversies in disputes about environmental impact and antagonism with other human activities (Papageorgiou, 2016).

Thus, maritime spatial planning has recently become a subject of significant interest to maritime countries. It is considered in the broadest sense, as defined in Directive 2014/89/EU, as the process by which public authorities examine and systemize human activities in marine areas to meet the ecological, economic, and social goals.

MSP is explained as the conception and foundation of a more reasonable planning and structuring of the use of marine space and the interactions between its uses, to stabilize development demands with the necessity to secure the environment, and to acquire the social and economic goals in an open and planned approach (Dover, 2008). It is a procedure for investigating and assigning parts of threedimensional marine spaces to certain or unused uses, to attain the ecological, economic, and social goals that are generally stipulated through a political process (Tsilimigkas \& Rempis, 2017).

The European MSP Directive focuses on promoting the long-lasting development of marine areas and the reasonable use of marine supplies. Marine and coastal activities are often closely linked, and human activities can have a serious impact on economic development and growth in coastal areas. At the same time, the welfare and economic development of a coastal area are bluntly related to the sustainable use of maritime space (Ehler \& Douvere, 2007). Therefore, maritime planning must include information on the impact of human activity on the environment.

On the other hand, according to recital 21 of Directive 2014/89/EU, the management of marine areas is intricate and requires the engagement of authorities, economic operators, and other stakeholders at different levels, considering that business stakeholders have better knowledge and understanding regarding the interests of the sector (Luhtala et al., 2021). To encourage effective and sustainable growth, stakeholders, authorities, and the public must be consulted.

The involvement and engagement of stakeholders for the sustainable expansion of coastal and marine areas are broadly recognized and assumed useful for acquiring local knowledge, ensuring a learning process and evading disputes, and establishing confidence between stakeholders (Schumacher et al., 2018). Stakeholder theory can be seen as a theory of management based on the premise of sustainable development, and the construction of sustainability incorporates the interests of stakeholders (Dimitrovski et al., 2021).

\section{METHODOLOGY AND DATA}

In 2019 with the start of the MARSPLAN BS-II project, the planning of public participation actions of stakeholders to identify areas and important features for each maritime activity to develop and implement the maritime spatial planning plan, creating a list of affected stakeholders began.

To achieve the research objectives, we developed a semi-structured questionnaire, with open and closed questions, regarding the tourist activity in the Black Sea coastal area from the stakeholders' perspective. The online questionnaire was used to gain an image of stakeholders' perceptions of coastal environmental issues and to prioritize important aspects of coastal and maritime tourism that are often controversial in terms of their impact on the environment of coastal areas. This research, which was addressed to stakeholders and to those involved in the process of developing and implementing maritime spatial planning, is part of a larger study on the integrated and up-to-date analysis of maritime/environmental conflicts/synergies.

The analyzed sample consists of 71 participants - stakeholders, each with economic, ecological, planning, research, and/or decisioninterests regarding the use of marine space. The structural analysis of the sample highlighted 32 
public sector entities: national, regional, and local authorities, research institutes, universities or educational institutions, and 39 private sector entities: local and national economic agents, and NGOs. Approximately $86 \%$ of the respondents work in the coastal area, more precisely in Constanța and Tulcea counties, with the rest operating in territories adjacent to the analyzed coastal area.

Data processing, systematization of results, and obtaining indicators used for the statistical analysis were accomplished by applying the Statistical Program for the Social Sciences (SPSS).

The study used the Grounded Theory (GT) as a research methodology, a method based on a progressive identification of semantic categories obtained from the direct analysis of a sample belonging to the investigated population stakeholders, aiming to generate a theoretical image of the studied social phenomenon, and not to test an existing theory or hypothesis. Differently stated, through cross-tabulation procedures, we undertook exploratory research of some environmental problems on the Romanian coastal area, within maritime spatial planning, because, at present, there is no satisfactory approach in this regard. Grounded Theory was approached epistemologically in a post-positivist manner, abandoning the reporting of gaps existing in the literature, trying a direct, exploratory approach to data, as they were collected in the field, then performing inductive processing of them. The obtained results allowed us a certain degree of generalization, which helped us obtain an interpretive model of the studied social phenomenon (Charmaz, 2008), namely, an assessment of stakeholders' perception of the impact of tourism in the Romanian Black Sea coastal area on the environment. Grounded Theory starts, like the other research methods, from a series of objective investigative questions that guide the direction in which the research will be deepened.

\section{RESULTS AND DISCUSSION}

The first aspect considered was to highlight the degree of knowledge regarding the following statement: Is a protected area an asset for future generations? $93 \%$ of stakeholders fully agree with this statement, compared to $7 \%$ who partially agree, which shows the awareness that the existing resources must be preserved for future generations.

Public participation involves unrestricted access to information on the environment and its resources; the level of information and education on environmental issues is very important. In this regard, one of the issues brought to the attention of stakeholders was to see how important their concerns are for: pollution control and prevention, education and public involvement, assistance programs for economic agents, and authorization and regulation for commercial customers in the development of tourism on the Black Sea coastal area, within maritime spatial planning. The structure of the answers to all four questions was the same, namely, $98.6 \%$ of stakeholders said that these concerns were important, while only $1.4 \%$ said they did not know. The invariability of the responses received denotes the very high level of information and education on the provisions of the European Union regarding integrated pollution prevention and control, the mandatory environmental conditions to be respected, on the one hand, and the fact that stakeholders can take responsibility for the prevention and control of pollution that could be caused by their activities.

Recent, multidisciplinary and interdisciplinary research has shown that tourism is a growing activity, with a multidimensional character and an evolving disposition to overcome the coastal and marine area, which is a pretty frail ecosystem. Therefore, when asked: How do you appreciate the quality of marine ecosystems on the Romanian Black Sea coast? and Do you believe it is important to establish diving areas where fishing is prohibited in any form? the structure of the answers received was identical, $53.5 \%$ considering it as being good, while $46.5 \%$ considered it bad (see Table 1). From these responses, it can be seen that stakeholders have a perception of the threats to marine ecosystems. 
Table 1: Distribution for the quality of marine ecosystem

\begin{tabular}{|l|c|l|l|l|}
\hline \multicolumn{1}{|c|}{ Valid } & Frequency & Percent & Valid percent & Cumulative percent \\
\hline Good & 38 & 53.5 & 53.5 & 53.5 \\
\hline Bad & 33 & 46.5 & 46.5 & 100 \\
\hline Total & 71 & 100 & 100 & \\
\hline
\end{tabular}

Source: author's work.

Natura 2000 is the main tool for preserving the natural heritage on the European Union territory. In this sense, to preserve the favorable conservation condition of species and habitats, the Black Sea ROSPA0076 Natura 2000 site, was declared by H.G. 1284/2007 regarding the designation of unique avifauna conservation areas, as an essential part of the European ecological network Natura 2000 in Romania. Thus, when asked: Do you know that the
Romanian Black Sea coast is part of the Natura 2000 protected natural area? $80.3 \%$ answered in the affirmative, while only $19.7 \%$ stated that they did not know this decision (see Table 2). Clearly, stakeholders are aware that all these regulations aim to ensure the conservation and maintenance of existing bird species and their specific habitats, which is why adequate management must be ensured.

Table 2: Distribution for Natura 2000 protected area

\begin{tabular}{|l|l|l|l|l|}
\hline \multicolumn{1}{|c|}{ Valid } & Frequency & Percent & Valid percent & Cumulative percent \\
\hline Yes & 57 & 80.3 & 80.3 & 80.3 \\
\hline No & 14 & 19.7 & 19.7 & 100 \\
\hline Total & 71 & 100 & 100 & \\
\hline
\end{tabular}

Source: author's work.

It is well known that coastal areas have a major role in socio-economic development given the multitude of economic activities: tourism, maritime transport, fishing and aquaculture, oil and gas research and extraction, cables and pipelines, etc. In this context, out of the number of stakeholders who were asked: Which are the main economic and social problems in the coastal area of the Black Sea? almost half, namely, $42.3 \%$ indicated inadequate, outdated, unmodernized infrastructure. On the other hand, $19.7 \%$ believe that pollution prevention and control is a problem, $18.3 \%$ believe that the authorization and regulation of economic activities for commercial customers is a problem, while $14.1 \%$ believe that it is the lack of transport infrastructure, and only $5.6 \%$ indicate the protection and restoration of the river basin (see Table 3). Therefore, the main problem identified cannot be eliminated from the research results, namely the importance of the economic and social development of human activities in the coastal area; this is also essential from an environmental perspective, as the sustainability of the coastal zone can only be attained by achieving a symmetry between the three piles, namely the economic, environmental and social. 
Table 3: Distribution for the main problems in the coastal area

\begin{tabular}{|l|l|l|l|c|}
\hline \multicolumn{1}{|c|}{ Valid } & Frequency & Percent & $\begin{array}{l}\text { Valid } \\
\text { percent }\end{array}$ & $\begin{array}{l}\text { Cumulative } \\
\text { percent }\end{array}$ \\
\hline $\begin{array}{l}\text { Authorization and regulation of } \\
\text { economic activities for commercial } \\
\text { customers }\end{array}$ & 13 & 18.3 & 18.3 & 18.3 \\
\hline $\begin{array}{l}\text { Inadequate/outdated/unmodernized } \\
\text { infrastructure }\end{array}$ & 30 & 42.3 & 42.3 & 60.6 \\
\hline Lack of transport infrastructure & 10 & 14.1 & 14.1 & 74.6 \\
\hline Pollution prevention and control & 14 & 19.7 & 19.7 & 94.4 \\
\hline $\begin{array}{l}\text { Protection and restoration of the river } \\
\text { basin }\end{array}$ & 4 & 5.6 & 5.6 & 100 \\
\hline Total & 71 & 100 & 100 & \\
\hline
\end{tabular}

Source: author's work.

A particularly important issue is that of environmental certifications. When asked about environmental quality or sustainable tourism certificates: Does your entity have a certificate?

Table 4: Distribution for achieving a quality certificate

\begin{tabular}{|l|c|l|l|l|}
\hline & Frequency & Percent & $\begin{array}{c}\text { Valid } \\
\text { percent }\end{array}$ & $\begin{array}{c}\text { Cumulative } \\
\text { percent }\end{array}$ \\
\hline We have already got one & 13 & 18.4 & 18.4 & 18.4 \\
\hline $\begin{array}{l}\text { We would like to get one, but we have } \\
\text { not taken any steps in this regard }\end{array}$ & 29 & 40.8 & 40.8 & 59.2 \\
\hline We think it's a useless tool & 29 & 40.8 & 40.8 & 100 \\
\hline Total & 71 & 100 & 100 & \\
\hline
\end{tabular}

Source: author's work.

$18.4 \%$ stated that they had already obtained one, $40.8 \%$ wanted to obtain one but did not take action in this regard, while another 40.8\% considered it a useless tool (see Table 4). The fact that all respondents are aware of the environmental certification standards for tourism (environmentally certified hotels, clean and certified beaches, etc.), is a positive aspect in the process of stimulating the development of a high-quality tourism sector, showing respect for resources natural. However, the small number of certified entities in the Romanian coastal area leads us to the idea that a better involvement of the competent public administration authorities is necessary, given that tourism is a cross-cutting economic activity that has a major impact on the environment. The idea is also supported by the response of stakeholders to the following statement: If we do not preserve the coast and the sea, with regulations and prohibitions, natural and archaeological sites will gradually lose their charm and attractiveness to tourists, and the socio-economic situation will worsen, $95.8 \%$ of the entities agreed with this statement, while only $4.2 \%$ disagreed (see Table 5 ). 
Table 5: Distribution regarding the regulations in the natural and archaeological sites

\begin{tabular}{|l|l|l|l|l|}
\hline \multicolumn{1}{|c|}{ Valid } & Frequency & Percent & Valid percent & Cumulative percent \\
\hline Agreement & 68 & 95.8 & 95.8 & 95.8 \\
\hline Disagreement & 3 & 4.2 & 4.2 & 100 \\
\hline Total & 71 & 100 & 100 & \\
\hline
\end{tabular}

Source: author's work.

Maritime spatial planning contributes to and enables the application of the Europe 2020 Strategy, which aims, inter alia, to promote a more competitive, resource-efficient, and greener economy. Therefore, another aspect considered was the investigation of stakeholders regarding MSP. To the question: Do you think that maritime spatial planning is a stimulus or an obstacle to the economic and social development of the area? 52\% answered in the affirmative, while $23 \%$ answered in the negative, and $25 \%$ of them considered that local public administration authorities should pay more attention to: protection, conservation, and development of the coastal zone; raising awareness of the impact of pollution on the environment and human health; information, communication, participatory planning by involving local communities in initiating and conducting local projects; digitization and concentration of information in an interactive platform; improving the infrastructure for economic development and tourism, in particular; increased involvement in tourism and sanitation activities on the coastal area; updating the legislative framework, monitoring, and control of economic activities so that the marine ecosystem is protected by the application of sanctions for non-compliance; training courses in the field of maritime spatial planning; achieving a strategy for the development of tourism in the coastal area that globalizes environment promoting measures. What is interesting to note is that $77 \%$ of stakeholders consider MSP to be a stimulus for the economic and social development of the coastal zone by creating new economic opportunities for the benefit of the marine ecosystem quality.

Therefore, the assessment of stakeholders' perceptions of coastal maritime planning shows that ecosystem services need to be integrated into planning decisions, which can bring a noteworthy contribution to attaining a proper ecological status in the Black Sea.

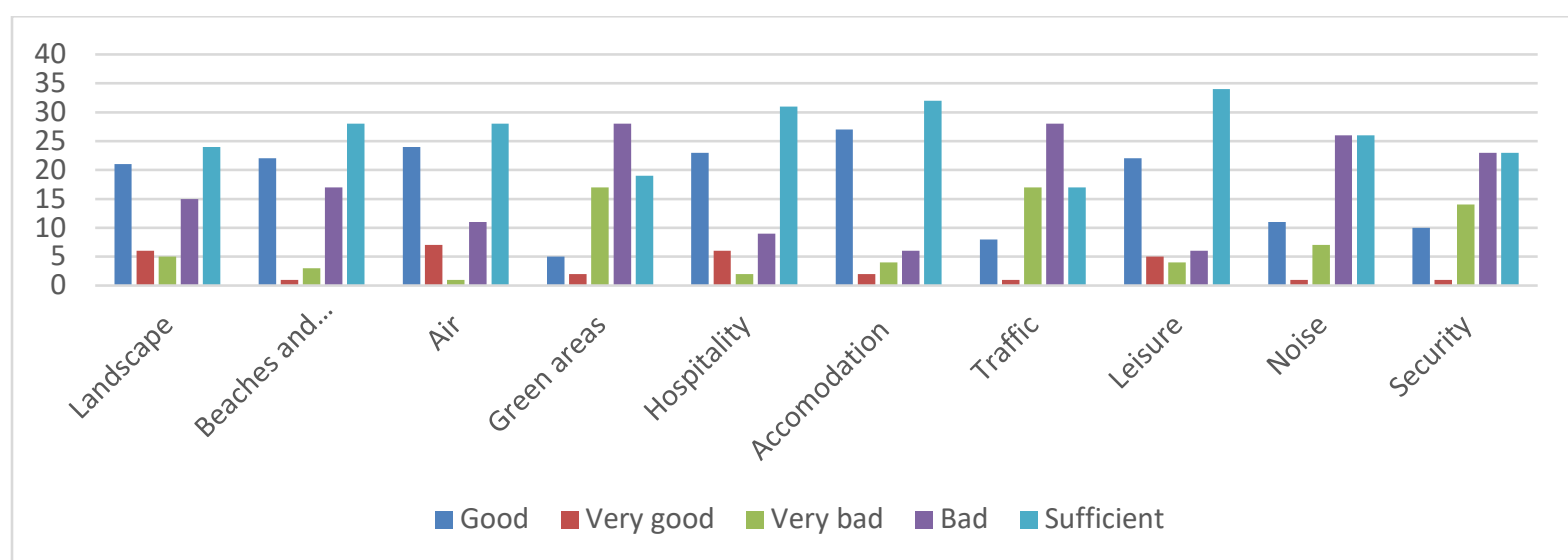

Figure 1: Assessing the perception of stakeholders regarding the environmental quality in the Romanian Black Sea coastal area.

Source: author's work. 
In this context, stakeholders were asked: How do they assess the quality of environmental issues and coastal infrastructure? Thus, regarding the landscape, $38.1 \%$ consider it to be very good and good, $33.8 \%$ consider it to be sufficient, and $28.1 \%$ consider it to be bad and very bad. Beaches and seaside are positively rated by $32.4 \%$, and $28.2 \%$ rate them as negative and $39.4 \%$ as sufficient. $63.4 \%$ are dissatisfied with green areas, $26.8 \%$ consider them sufficient and only $9.8 \%$ are satisfied. The air quality is considered to be good by $43.7 \%, 16.9 \%$ consider it negative and $39.4 \%$ consider it sufficient. The noise level is perceived as optimal by $16.9 \%$, while $46.5 \%$ perceive it as discomfort, and $36.6 \%$ as sufficient (see Figure 1 ). It can be concluded that the perception of stakeholders regarding the quality of some environmental issues in the coastal area does not generally benefit from a positive assessment.

In general, respondents were very pleased with the issues related to coastal infrastructure. Thus, the problem of hospitality is positively assessed by $40.9 \%$, while $43.7 \%$ consider it sufficient and only $15.4 \%$ appreciate it negatively. Regarding the hospitality industry, accommodation and restaurants are favorably appreciated, as good and very good, by $40.8 \%$; while $45.1 \%$ consider them sufficient and only $14.1 \%$ are dissatisfied. The least favorable evaluation, with low and very poor scores, was made to the traffic variable, by $63.3 \%$ of the surveyed stakeholders, $23.9 \%$ appreciating it as sufficient, and only $12.8 \%$ as good. $38 \%$ are satisfied with the leisure and entertainment feature, while $14.1 \%$ have a negative perception, and $47.9 \%$ consider that they are enough. Regarding security, $52.1 \%$ of respondents rate it negatively, while $32.4 \%$ rate it as sufficient and only $15.5 \%$ have a positive rating. The entities' perception regarding the price level is satisfactory for $28.2 \%, 46.5 \%$ considering that they are sufficient, and $25.4 \%$ declaring that they are not satisfied (see Figure 1). It can be seen that the perception of stakeholders on this issue is more favorable.

One conclusion that can be drawn is that stakeholders perceived the quality of the environment compared to that for coastal infrastructure as having higher importance, even if only $18.4 \%$ of respondents specified that they had obtained environmental certification for tourism.

\section{CONCLUSION AND RECOMMENDATION}

Maritime spatial planning is believed to be an indispensable aid for the successful integration of maritime policy. Thus the coastal zone management policy must aim at its sustainable development, namely, one that responds to current needs without constraining the needs of future generations.

Although the relevant stakeholders consulted are heterogeneous, the most important stakeholder being the public sector represented by the local public administration (Aivaz et al., 2021), the results obtained by the research team are considered beneficial and homogeneous, as there are no significant perception differences of private and public stakeholders. Thus, following the evaluation of stakeholders' views on the impact of tourism on the environment, the following barriers were identified from the perspective of maritime spatial planning in the Black Sea: lack of appropriate digitization that can concentrate information in an interactive platform; the tourism sector is fragmented and its management at the level of the coastal area, uncoordinated; lack of policies and competent management of public administration authorities; environmental pollution.

Therefore, sustainable tourism, stemming from the principles of sustainable development, takes full account of its current and future economic, social and environmental impact (UNEP, 2005), and its planning requires the stakeholders' support to meet their needs (Wang et al., 2016).

Papageorgiou (2016) stated that even if the impact of tourism on the environment cannot be studied in-depth and fully proven, and even if coastal and maritime tourism is generally perceived as activities that do not threaten other human uses, it is mainly accepted that this particular kind of industry should be exposed to considerable management and planning efforts.

Therefore, coastal areas represent major economic and environmental challenges for sustainable development, for ensuring long-term sustainability, and for adapting spatial maritime planning to the specifics of the area, and transdisciplinary collaboration is needed between stakeholders.

In this context, the results of our research can also be beneficial to all countries that promote 
sustainable tourism in general, and coastal tourism in particular, as they are part of the concerns about good practices in this field. Undoubtedly, tourism must be regarded as a door to the future for all regions in the world and can offer new horizons for travelers, investors, and authorities.

\section{ACKNOWLEDGEMENTS}

This work has been funded and supported by the European Commission through the European Maritime and Fisheries Fund, Cross-border Maritime Spatial Planning for Black Sea - Bulgaria and Romania (MARSPLAN-BS-II), EASME/EMFF/ 2018/1.2.1.5/01/SI2.806725- MARSPLAN-BS-II.

\section{REFERENCES}

Aivaz, K., Stan, M.I., Vintilă, D.F., \& Ionițiu, I. (2021). Considerations of public and private entities on tourism in the Romanian coastal area in the context of Maritime Spatial Planning. In Pamfilie, R. et al. (Eds.), BASIQ International Conference: New Trends in Sustainable Business and Consumption (pp. 151-157). Bucharest, RO: ASE

Avoyan, E., Tatenhove, J.v., \& Toonen, H. (2017). The performance of the Black Sea Commission as a collaborative governance regime. Marine Policy, 81, 285-292. https://doi.org/10.1016/j.marpol.2017.04.006

Berezina, O., Honcharenko, I., \& Berezhna, L. (2020). Future of household resources and expenditure as the indicators of sustainable development in Ukraine. Journal of Eastern European and Central Asian Research, 73), 280-291.

https://doi.org/10.15549/jeecar.v7i3.431

Charmaz, K. (2008). Constructionism and the Grounded Theory. In J.A Holstein \& J.F Gubrin (Eds.) Handbook of Constructionist Research, (pp. 397-412). New York: The Gulford Press

Dimitrovski, D., Lemmetyinen, A., Nieminen, L., \& Pohjola, T. (2021) Understanding coastal and marine tourism sustainability - A multistakeholder analysis. Journal of Destination Marketing \& Management, 19, 100554. https://doi.org/10.1016/j.jdmm.2021.100554

Directive 2014/89/EU of the European Parliament and of the Council of 23 July 2014 establishing a framework for maritime spatial planning. https://eur-

lex.europa.eu/legal-

content/EN/TXT/?uri=celex\%3A32014L0089

Douvere, F. (2008). The importance of marine spatial planning in advancing ecosystembased sea use management. Marine Policy, 32(5), 762-771.

https://doi.org/10.1016/j.marpol.2008.03.021

Ehler, C. (2014). A Guide to Evaluating Marine Spatial Plans. UNESCO, Paris.

https://unesdoc.unesco.org/ark:/48223/pf000 0227779

Ehler, C., \& Douvere, F. (2007). Visions for a Sea change: Report of the First International Workshop on Marine Spatial Planning, Intergovernmental Oceanographic Commission and the Man and the Biosphere Programme UNESCO Headquarters. Paris, France. 8-10 November 2006. Paris, France, UNESCO, 83pp. (Intergovernmental Oceanographic Commission Manuals and Guides; 46). http://hdl.handle.net/11329/204

Filip, C., Stan, M.I., \& Vintilă, D.F. (2016). Multicriteria analysis of urban development in the Romanian Black Sea coastal zone.

Proceedings of the 16th International Multidisciplinary Scientific GeoConference SGEM 2016, 6(3), pp. 569-576, DOI: 10.5593/SGEM2016/HB63/S10.073

Luhtala, H., Erkkilä-Välimäki, A., Eliasen, S.Q., \& Tolvanen, H. (2021). Business sector involvement in maritime spatial planning Experiences from the Baltic Sea region. Marine Policy, 123, 104301. https://doi.org/10.1016/j.marpol.2020.104301

Gómez-Ballesteros, M., Cervera - Núñez, C., Campillos-Llanos, M., Quintela, A., Sousa, L., Marques, M., Alves, F.L., Murciano, C., Alloncle, N., Sala, P., Lloret, A., Simão, A.P., Costa, A.C., Carval, D., Bailly, D., Nys, C., Sybill, H., \& Dilasser, J. (2021). Transboundary cooperation and mechanisms for Maritime Spatial Planning implementation. SIMNORAT project. Marine Policy, 127, 104434. https://doi.org/10.1016/j.marpol.2021.104434

Luhtala, H., Erkkilä-Välimäki, A., Eliasen, S.Q., \& Tolvanen, H. (2021). Business sector involvement in maritime spatial planning Experiences from the Baltic Sea region. 
Marine Policy, 123, 104301.

https://doi.org/10.1016/j.marpol.2020.10430 1

Megits, N., Neskorodieva, I., \& Schuster, J. (2020). Impact assessment of the COVID-19 on trade between Eastern Europe and China. Journal of Eastern European and Central Asian Research (JEECAR), 73), 385-399. https://doi.org/10.15549/jeecar.v7i3.579

Munteanu, I. (2021). Exploring the Nexus Between the Construction Industry and Sustainable Tourism in an Emerging Economy. Monograph: Under the pressure of digitalizations: challenges and solutions at organizational and industrial levels, (pp.9398). Filodiritto Proceedings.

Ólafsdóttir, R. (2020). The Role of Public Participation for Determining Sustainability Indicators for Arctic Tourism. Sustainability, 13(1), 295. http://dx.doi.org/10.3390/su13010295.

Papageorgiou, M. (2016). Coastal and marine tourism: A challenging factor in Marine Spatial Planning. Ocean \& Coastal Management, 129, 44-48. https://doi.org/10.1016/j.ocecoaman.2016.05. 006

Petrișor, A.I. (2014). Methodology for assessing environmental quality in the Romanian coastal area using GIS. Urbanism. Architecture. Constructions, 5(3), 69-72.

Petrişor A.I. (2014). The territorial competitiveness of sustainability cannot be assessed by a single domain, Urbanism. Architecture. Constructions, 5(4), 27-34.

Petrişor, A.I. (2017). A diversity-based approach to the spatial development of socioecological systems. Urbanism. Architecture. Constructions, 8(2), 143-162.

Petrişor, A.I., Susa, A.A., Petrişor, L.E. (2020). Counting for sustainability: the risks of creating a market for the environment. PESD, 14(1), 167-184. https://doi.org/10.15551/pesd2020141013

Petrișor, A.I., Hamma, W., Nguyen, H.D., Randazzo, G., Muzirafuti, A., Stan, M.I., Tran, V.T., Aștefănoaiei, R., Bui, Q.T., Vintilă, D.F., Truong, Q.H., Lixăndroiu, C., Țenea, D.D., Sîrodoev, I. \& Ianoş, I. (2020). Degradation of Coastlines under the Pressure of
Urbanization and Tourism: Evidence on the Change of Land Systems from Europe, Asia and Africa. Land, 9(8), 275. http://dx.doi.org/10.3390/land9080275

Rempis, N., Alexandrakis, G., Tsilimigkas, G., \& Kampanis, N. (2018). Coastal use synergies and conflicts evaluation in the framework of spatial, development and sectoral policies. Ocean \& Coastal Management, 166, 40-51. https://doi.org/10.1016/j.ocecoaman.2018.03. 009

Schumacher, J., Schernewski, G., Bielecka, M., Loizides, M.I., \& Loizidou, X.I. (2018). Methodologies to support coastal management - A stakeholder preference and planning tool and its application. Marine Policy, 94, 150-157. https://doi.org/10.1016/j.marpol.2018.05.017

Shpak, N., Melnyk, O., Horbal, N., Ruda, M., \& Sroka W. (2021). Assessing the implementation of the circular economy in the EU countries. Forum Scientiae Oeconomia, $9(1), 25-39$. DOI: 10.23762/FSO_VOL9_NO1_2

Tsilimigkas, G., \& Rempis, N. (2017). Maritime spatial planning and spatial planning: Synergy issues and incompatibilities. Evidence from Crete island, Greece. Ocean \& Coastal Management, 139, 33-41. https://doi.org/10.1016/j.ocecoaman.2017.02. 001

United Nations Environment Programme (UNEP) \& World Tourism Organization. (2005). Making Tourism More Sustainable: A Guide for Policy Makers, Paris, France. https://wedocs.unep.org/bitstream/handle/2 $0.500 .11822 / 8741 /-$ Making\%20Tourism\%20More\%20Sustainable \%20A\%20Guide\%20for\%20Policy\%20Makers2005445.pdf? sequence=3\&isAllowed $=\mathrm{y}$

Văidianu, N., \& Ristea, M. (2018). Marine spatial planning in Romania: State of the art and evidence from stakeholders. Ocean \& Coastal Management, 166, 52-61. https://doi.org/10.1016/j.ocecoaman.2018.03. 017

Wang, S.-H., Lee, M.-T., Château, P.-A., \& Chang, Y.-C. (2016). Performance Indicator Framework for Evaluation of Sustainable Tourism in the Taiwan Coastal Zone. 
Sustainability, $8(7), 652$.

https://doi.org/10.3390/su8070652

\section{ABOUT THE AUTHORS}

Mari-Isabella Stan, email: stanisabella@yahoo.com

Dr. Mari-Isabella Stan is a Lecturer at the Department of Administrative and Social Sciences, Faculty of Law and Administrative Sciences, Ovidius University of Constanţa, in Romania. She completed two Master's Programs: "Coastal Engineering" in 1998 and "Public Policy and Public Administration" in 2002 and received her Ph.D. degree in 2007. Research interest: coastal construction, Urbanism, project management, maritime spatial planning.

Dr. Habil. Kamer Ainur Aivaz is a professor at the Ovidius University of Constanta, Romania. She is the author of more than 150 journal articles. She received a postdoctoral fellowship from the Romanian Academy between 2011 and 2013 and the Habilitation degree in Cybernetics and Statistics in 2017. Her main fields of interest include statistics, econometrics, and data analysis.

Dr. Dragoș-Florian Vintilă is a Lecturer at the Department of Civil Engineering, Faculty of Civil Engineering, Ovidius University of Constanța. He graduated from the Master's Program "Coastal Engineering" in 2001 and received his Ph.D. degree in 2010. He is a graduate (2017) of the Fulbright Scholarship at the University of Rochester in Entrepreneurship and Product Management. Research interest: maritime spatial planning, buildings retrofitting, entrepreneurship.

Dr. Ionela Ionițiu graduated from the Ovidius University of Constanta in 2001, followed by a Master's degree in 2002. She attended Al. I. Cuza University, Iași and received her Ph.D. degree in 2012. Her major field of study is English language teaching, mainly English, for specific purposes. 